\title{
A Study of Attributes of Hearing Impaired Children and Importance of Nutrition
}

\author{
P. Anubhuti ${ }^{*}$, R. Neela Rani ${ }^{1}$, S.L. Kameswari ${ }^{1}$ and P. Sreedevi ${ }^{2}$
}

${ }^{1}$ Department of Home Science Extension and communication management, ${ }^{2}$ Department of Human Development and Family Studies, Hyderabad, Professor Jayashankar Telangana

State Agricultural University, Andhra Pradesh, India

*Corresponding author

\section{A B S T R A C T}

A present study was conducted to study attributes of hearing impaired children and

\section{Keywords}

Hearing impaired children, Nutrition, Mean score, Action research

Article Info

Accepted: 06 June 2018 Available Online: 10 July 2018 importance of nutrition. For the study, based upon the nature of the research problem and objectives of the present study, action research design was selected. A total of fifteen hearing impaired children were selected. Questionnaire was developed for data collection. Mean score were used for data analysis. The results of the study were revealed that the majority of the hearing impaired children were male i.e. $60 \%$ when compared to female $40 \%$.More than half of the HI children i.e. 53\% were belonged under the category of 10-11 years of age followed by almost an equal sample belonged to 8-9 years old (27\%) and 6-7 years $(20 \%)$. In case of class of study the majority of hearing impaired children was in $5^{\text {th }}$ class i.e. $33 \%$, followed by class $4^{\text {th }}(27 \%)$. An equal sample i.e. $20 \%$ was belonging to class $1^{\text {st }}$ and $3^{\text {rd }}$ whereas none of them belonged to class $2^{\text {nd }}$. It was also found that respiratory problems among hearing impaired children was more prominent i.e. all the hearing impaired children were having respiratory problems followed by almost an equal sample of $80 \%$ were suffering from ear disorders and voice problems. Very few samples were having eyes problems $(40 \%)$ whereas none of them was having tooth decay.

\section{Introduction}

The WHO definition of "hearing impairment" refers to both complete and partial loss of ability to hear. Hearing loss, also known as hearing impairment, is a partial or total inability to hear. A deaf person has little to no hearing. Hearing loss may occur in one or both ears. In children hearing problems can affect the ability to learn spoken language and in adults it can cause work related difficulties. In some people, particularly older people, hearing loss can result in loneliness. Hearing loss can be temporary or permanent. The incidence of hearing impairment worldwide is 1 - 2 per 1,000 newborns (WHO, 2007).

According to WHO survey, In India, 63 million people (6.3\%) suffer from significant auditory loss. Four in every 1000 children 
suffer from severe to profound hearing loss. With over 100,000 babies that are born with hearing deficiency every year. The estimated prevalence of adult-onset deafness in India was found to be $7.6 \%$ and childhood onset deafness to be $2 \%$.With the ageing of the world population these numbers are expected to double by 2030-2050. Hearing impairment is considered the most prevalent impairment worldwide.

\section{Nutrition and hearing loss}

Hearing loss is a public health problem or a disability that appears in early life which increases several-fold over the lifespan, and also affects all societies. Hearing loss has profound health, social, and economic consequences. Hearing impaired children are likely to experience speech, language, and cognitive delays and poor school performance. Social isolation accompanies daily life of the hearing impaired. Micronutrient deficiencies that often coexist with generalized undernutrition at critical stages of development have been linked to hearing impairment. Severe prenatal iodine deficiency is listed by the WHO as a nutritional cause of hearing loss. In high-income countries, largepopulation studies in adults have reported protective risk ratios against hearing loss with higher dietary intakes of fish, long-chain PUFAs, folate, b-carotene, and vitamins A, E, and $\mathrm{C}$. Although findings across studies are inconsistent, animal evidence exists to support roles for each of these studied nutrients in regulating redox stress, protecting cochlear function, and enabling hearing.

Acute malnutrition raises children's susceptibility to infections, including in the ear. Repeated ear infections can lead to hearing loss (Hopkins, 2018). Acute undernutrition in early childhood, represented by a low BMI or thin arm circumference for age, was associated with both an 2-fold higher risk of hearing loss and a 1.4- to 1.8fold increased risk of abnormal tympanometry. (Emmett et al., 2018)

Kayalvizhi et al., (2017) conducted a crosssectional study to study the factors that can influence the consumption of fruits and vegetables among the selected sample of 500 school children between 13 to 15 years of age. The structured questionnaire was used for data collection. Results found that majority of boys had a positive attitude towards health and physical outcome expectancy than girls regarding consumption of fruits and vegetables. The study also indicated that boys and girls consumed less quantity of energy, carbohydrate, and protein when compared with RDA.

Bora and Kulshreshtha (2016) conducted a study of assessment of nutritional status of school going children age between 7-9 years and 100 children were selected randomly i.e. 50 boys and 50 girls. Nutritional status was assessed in terms of Dietary assessment which was done by 24 hours Dietary Recall method for 3 consecutive days. The results of the study revealed that consumption of foods like cereals, pulses, fruits, GLV's, milk and milk products, fats and oils, sugar and jaggery were inadequate in the diets of both boys and girls and nutrients like energy, fat, beta-carotene, B-complex vitamins, vitamin $\mathrm{C}$, iron and calcium were found limiting in the diets of school children. Hence the results of the study can be of used for planning need-based supplementary nutrition programs by the policy-makers for the school children.

Curhanet al., (2015) emphasizes the likely importance of micronutrient imbalance or deficiency as determinants of hearing loss. It is reported that higher intakes of $b$-carotene, $b$ cryptoxanthin, and folate to be protective against incident hearing loss. Oxidative stress and impaired homocysteine metabolism 
appear to contribute to inner-ear dysfunction, effects that adequate carotenoid and folate nutriture may attenuate by postulated scavenging of free radicals and maintenance of antioxidant enzyme homeostasis (MartinezVega $\mathrm{R}$ et al., 2015), respectively, although other mechanisms likely exist. While there are plausible mechanisms by which chronic protein and energy deprivation during development may interfere with ear formation and function in fetal and early postnatal stages (Rocinhol et al., 2001).

In low-income countries, where undernutrition remains widespread, limited research has identified micronutrient deficiencies (e.g., of vitamin A and zinc) as risk factors for otitis media, the leading acquired cause of childhood hearing loss. In one trial cohort, preschool vitamin A supplementation was shown to reduce hearing loss attributed to childhood purulent ear infection.(Schmitz et al., 2012).

\section{Materials and Methods}

For the study, based upon the nature of the research problem and objectives of the present study, Action research design was selected.

The city Hyderabad was purposely selected for the present study because of the availability and easy accessibility of the Hearing-Impaired schools. One school was purposively selected namely -John Peter Memorial (J.P.M) Junior College for the Deaf. A total fifteen sample were randomly selected.

The respondents were from Hearing impaired school and variable like general profile like sex, age, gender, class of study, health problems, diet category and frequency of food consumption was studied. Questionnaire was developed for the study to gather the information from the respondents.
The mean scores, percentage and frequency were calculated to know the food consumption and ranking was given.

\section{Results and Discussion}

The results of the present study were presented below.

The majority of the children were non vegetarian comprising of $60 \%$ followed by vegetarian $(40 \%)$. In case of their food consumption pattern all the samples were taking cereals and spices on daily basis followed by other vegetables, sugars, pulses $(93 \%)$, milk and milk products $(87 \%)$, roots and tubers $(73 \%)$, millets $(60 \%)$, green leafy vegetables and fruits (53\%).Very few of them were taking nuts and oil seeds (27\%) and meat and egg (13\%) on daily basis. More than half of the samples i.e. 53\% were taking nuts and oil seeds on weekly basis followed by meat and egg (47\%), fruits (40\%), roots and tubers, green leafy vegetables (27\%), millets $(20 \%)$, milk and milk products (13\%) and very few of them were taking other vegetables, pulses, sugars $(7 \%)$. None of them were taking cereals and spices weekly. Most of the respondents were taking millets, green leafy vegetables, nuts and oil seeds (20\%) occasionally while least of them were taking fruits occasionally (7\%). Nearly half i.e. $40 \%$ were never taking non veg because they are vegetarian.

Food stuffs were ranked according to the mean score obtained for each of them. Milk were ranked 1st having mean score of 4.0 and non-veg were ranked $10^{\text {th }}$ having least mean score i.e. 2.2 among them (Fig. 1-4).

\section{General profile of the respondents}

The study showed that $60 \%$ of the hearing impaired children were male while $40 \%$ of them were female. Shah et al., (2017) pointed that hearing impairment is slightly more 
common among boys than girls; the average male: female ratio is $1.24: 1$. The majority of the children $(53 \%)$ were in the age group of 10-11 year as compared to the children in age group 8-9 years (27\%) and in the age group of 6-7 years (20\%). Hussain et al., (2011) revealed that $\mathrm{HI}$ children between aged between $9-12(42.5 \%)$ years was Hearing
Impaired compared to children aged between $13-15$ years $(31.3 \%)$ and $5-8$ years $(27.2 \%)$.

The majority of the hearing impaired children were studying in class $5^{\text {th }}$ i.e. $33 \%$, followed by $27 \%$ in class $4^{\text {th }}, 20 \%$ in class $3^{\text {rd }}$ and class $1^{\text {st }}$ (Table 1-4).

Table.1 Frequency of food consumption

\begin{tabular}{|c|c|c|c|c|c|c|c|c|c|c|}
\hline \multirow[t]{2}{*}{ Food } & \multicolumn{2}{|c|}{$\begin{array}{l}\text { Daily } \\
\text { (4) }\end{array}$} & \multicolumn{2}{|c|}{$\begin{array}{l}\text { Weekly } \\
\text { (3) }\end{array}$} & \multicolumn{2}{|c|}{$\begin{array}{c}\text { Occasionally } \\
\text { (2) }\end{array}$} & \multicolumn{2}{|c|}{$\begin{array}{l}\text { Never } \\
\text { (1) }\end{array}$} & \multirow[t]{2}{*}{$\begin{array}{l}\text { Average } \\
\text { score }\end{array}$} & \multirow[t]{2}{*}{ Ranking } \\
\hline & $\mathbf{F}$ & $\%$ & $\mathbf{F}$ & $\%$ & $\mathbf{F}$ & $\%$ & $\mathbf{F}$ & $\%$ & & \\
\hline Cereals & 15 & 100 & - & - & - & - & - & - & 4.0 & $1^{\mathrm{st}}$ \\
\hline Spices & 15 & 100 & - & - & - & - & - & - & 4.0 & $1^{\mathrm{st}}$ \\
\hline Pulses & 14 & 93 & 1 & 7 & - & - & - & - & 3.9 & $2^{\text {nd }}$ \\
\hline $\begin{array}{l}\text { Milk and } \\
\text { milk } \\
\text { products }\end{array}$ & 13 & 87 & 2 & 13 & - & - & - & - & 3.9 & $2^{\text {nd }}$ \\
\hline $\begin{array}{c}\text { Other } \\
\text { vegetables }\end{array}$ & 14 & 93 & 1 & 7 & - & - & - & - & 3.9 & $2^{\text {nd }}$ \\
\hline Sugars & 14 & 93 & 1 & 7 & - & - & - & - & 3.9 & $2^{\text {nd }}$ \\
\hline $\begin{array}{c}\text { Roots and } \\
\text { tubers }\end{array}$ & 11 & 73 & 4 & 27 & - & - & - & - & 3.7 & $3^{\text {rd }}$ \\
\hline Fruits & 8 & 53 & 6 & 40 & 1 & 7 & - & - & 3.5 & $4^{\text {th }}$ \\
\hline Millets & 9 & 60 & 3 & 20 & 3 & 20 & - & - & 3.4 & $5^{\text {th }}$ \\
\hline $\begin{array}{c}\text { Green } \\
\text { leafy } \\
\text { vegetables }\end{array}$ & 8 & 53 & 4 & 27 & 3 & 20 & - & - & 3.3 & $6^{\text {th }}$ \\
\hline $\begin{array}{l}\text { Nuts and } \\
\text { oil seeds }\end{array}$ & 4 & 27 & 8 & 53 & 3 & 20 & - & - & 3.1 & $7^{\text {th }}$ \\
\hline $\begin{array}{l}\text { Meat and } \\
\text { egg }\end{array}$ & 2 & 13 & 7 & 47 & - & - & 6 & 40 & 2.3 & $8^{\text {th }}$ \\
\hline
\end{tabular}

Table. 2 Gender profile of hearing impaired children

\begin{tabular}{|l|l|l|}
\hline \multicolumn{1}{|c}{ Respondents } & \multicolumn{1}{c}{$\mathrm{G}=15$} \\
\hline HI Children & Male & \multicolumn{1}{c|}{$\mathrm{F}(\%)$} \\
& Female & $6(60 \%)$ \\
& & $6(40 \%)$ \\
\hline
\end{tabular}


Table.3 Age group of HI children

\begin{tabular}{|l|l|}
\hline \multicolumn{2}{|c|}{ Hearing impaired children } \\
\hline \multicolumn{1}{|c|}{ Age (yrs.) } & \multicolumn{1}{|c|}{$\mathrm{F}(\%)$} \\
\hline 6- 7 yrs. & $3(20 \%)$ \\
\hline 8- 9 yrs. & $4(27 \%)$ \\
\hline 10- 11 yrs. & $8(53 \%)$ \\
\hline
\end{tabular}

Table.4 Class of studyof hearing impaired children

\begin{tabular}{|c|c|c|}
\hline S. No. & Class of study & $\mathrm{F}(\%)$ \\
\hline 1. & $1^{\text {st }}$ & $3(20 \%)$ \\
\hline 2. & $2^{\text {nd }}$ & $0(0 \%)$ \\
\hline 3. & $3^{\text {rd }}$ & $3(20 \%)$ \\
\hline 4. & $4^{\text {th }}$ & $4(27 \%)$ \\
\hline 5. & $5^{\text {th }}$ & $5(33 \%)$ \\
\hline
\end{tabular}

Figure.1 Gender profile of hearing impaired children

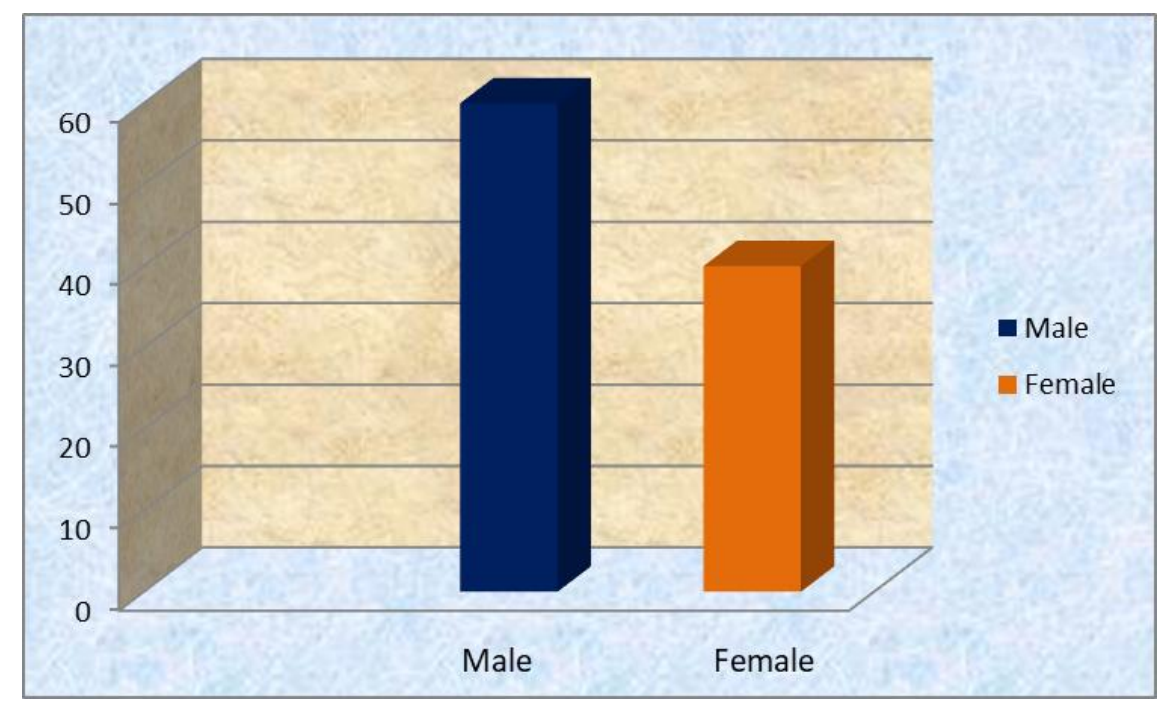


Figure.2 Age of hearing impaired children

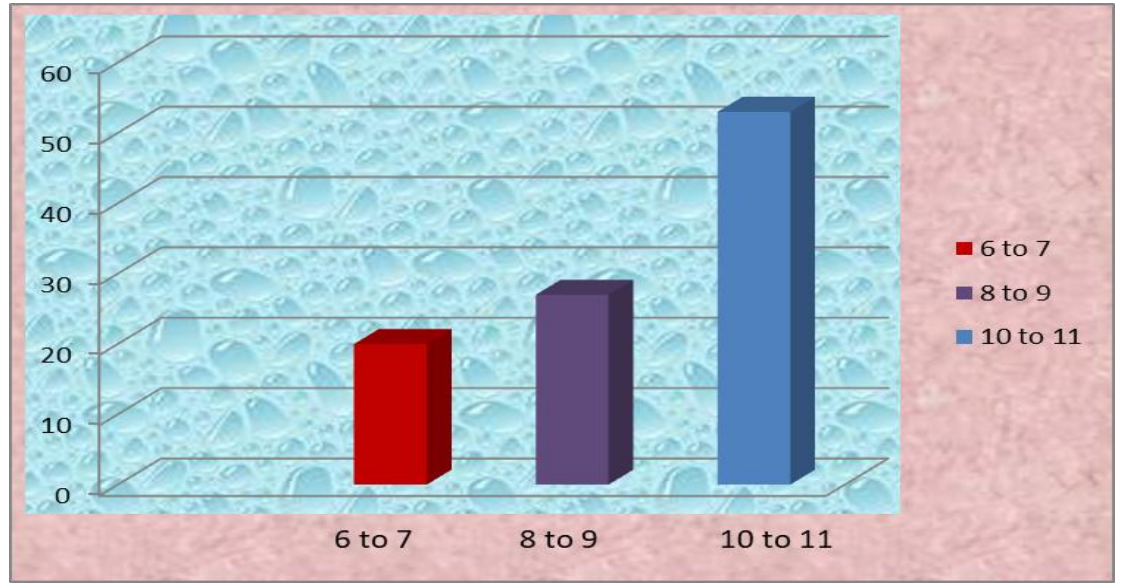

Figure.3 Class of study ofhearing impaired children

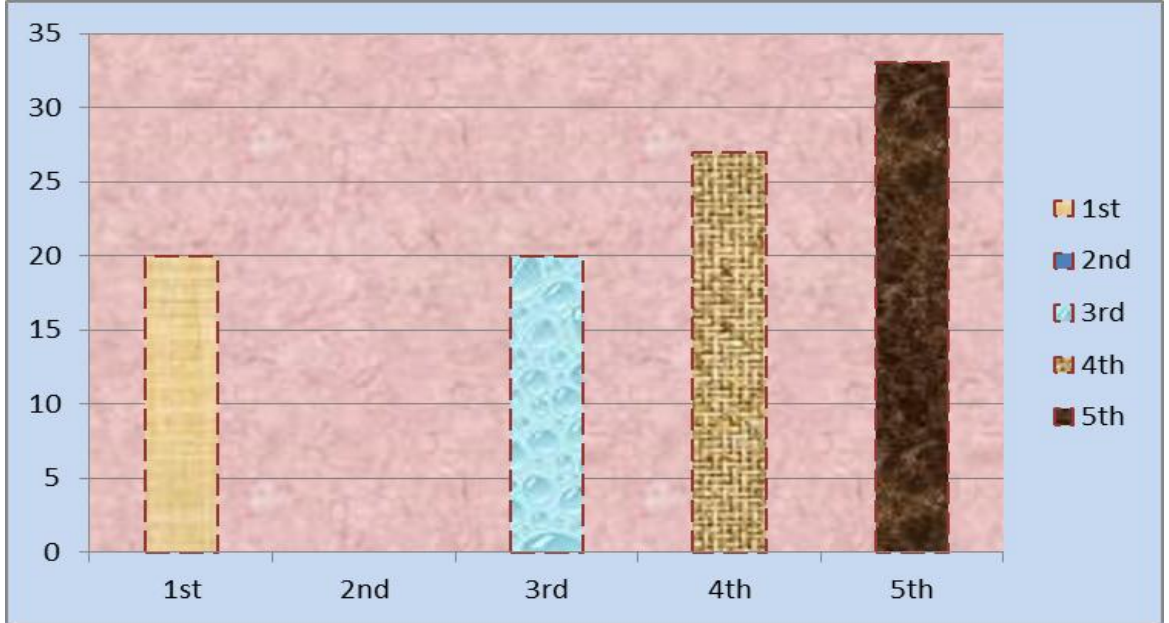

Figure.4 General health problems of hearing impaired children

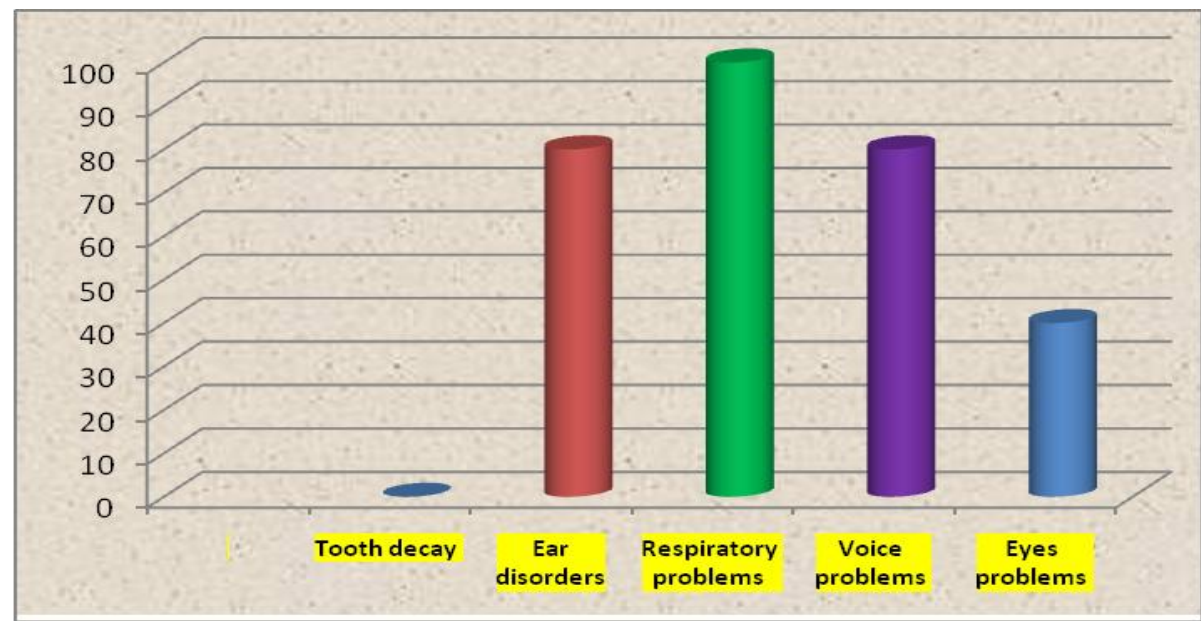


All the hearing impaired children in the study were found to be suffering from respiratory problems, followed by $(80 \%)$ children with ear disorders and voice problems, $(40 \%)$ with eyes problems and none of them were found to have tooth decay problems. Susan and Satish (2018), found similar results which revealed that respiratory efficiency of Hearing Impaired was lower than the normal and it was due to the lack of the development of a verbal language in Hearing Impaired. Ostadimoghaddam et al., (2015) revealed that the hearing impaired children have significantly more eye problems than normal children.

The study revealed that $95 \%$ of the hearing impaired children were born to the normal parents and all the children were having congenital hearing loss. The term congenital hearing loss means that hearing loss is present at birth. Congenital hearing loss can be caused by genetic or non-genetic (acquired) factors. Non-genetic factors that are known to cause congenital hearing loss are linked to pregnancy and birth delivery. National Deaf Children's Society (2015) stated that there is a wide variation in the causes of deafness and because of this 9 out of 10 deaf children are born to hearing parents and 1 out of 10 children born to deaf parents are also deaf.

From the study, it was concluded that. The majority of the hearing impaired children were male i.e. $60 \%$ when compared to female $40 \%$.More than half of the HI children i.e. $53 \%$ were belonged under the category of 10 11 years of age followed by almost an equal sample belonged to 8-9 years old (27\%) and 6-7 years $(20 \%)$. In case of class of study the majority of hearing impaired children was in $5^{\text {th }}$ class i.e. $33 \%$, followed by class $4^{\text {th }}(27 \%)$. An equal sample i.e. 20\% was belonging to class $1^{\text {st }}$ and $3^{\text {rd }}$ whereas none of them belonged to class $2^{\text {nd }}$.
The majority of the children were non vegetarian comprising of $60 \%$ followed by vegetarian $(40 \%)$. In case of their food consumption pattern all the samples were taking cereals and spices on daily basis followed by other vegetables, sugars, pulses (93\%), milk and milk products (87\%), roots and tubers $(73 \%)$, millets $(60 \%)$, green leafy vegetables and fruits $(53 \%)$.

Food stuffs were ranked according to the mean score obtained for each of them. Milk were ranked 1 st having mean score of 4.0 and non-veg were ranked $10^{\text {th }}$ having least mean score i.e. 2.2 among them.

It was also found that respiratory problems among hearing impaired children was more prominent i.e. all the hearing impaired children were having respiratory problems followed by almost an equal sample of $80 \%$ were suffering from ear disorders and voice problems. Very few samples were having eyes problems $(40 \%)$ whereas none of them was having tooth decay.

\section{References}

Bora, P. and Kulshreshtha, K. 2016.Assessment of nutritional status of school going children in the age group 7-9 Years. Asian Journal of Home Science.11(1): 238-245.

Curhan SG, Stankovic KM, Eavey RD, Wang M, Stampfer MJ, Curhan GC. Carotenoids, vitamin $\mathrm{A}$, vitamin $\mathrm{C}$, vitamin $\mathrm{E}$, and folate and risk of selfreported hearing loss in women. Am J ClinNutr 2015;102:1167-75.

Emmett, S.D., Schmitz, J., Karna, S.L., Khatry, S.K., Wu, L., LeClerq, S.C., Pillion, J., and West, K.P. 2018. Early childhood undernutrition increases risk of hearing loss in young adulthood in rural Nepal. American Society for Nutrition. 107(2):268-277. 
Hussein, K.Q.2015. Developing and evaluating a multiple- task Arabic edictionary for Arab deaf persons. International Journal of Latest Research in Science and Technology. 4(1):56-61.

Kayalvizhi, K., John, S., and Sivapriya, T. 2017. Psychosocial Factors Influencing Fruit and Vegetable Consumption and the Nutrient Intake of Rural School Children in Vedaraniyam. Indian Journal of Research in Food Science and Nutrition. 4(1): 24- 30.

Ostadimoghaddam, H., Mirhajian, H., Yekta, A.A. D.S., Heravian, J., Malekifar, A., and Khabazkhoob, M. 2015.Eye problems in children with hearing impairment. Journal of Current
Ophthalmology.27: 56-59.

Schmitz J, West KP Jr., Khatry SK, Wu L, LeClerq SC, Karna SL, Katz J, Sommer A, Pillion J. Vitamin A supplementation in preschool children and risk of hearing loss as adolescents and young adults in rural Nepal: randomized trial cohort follow-up study. BMJ 2012;344:d7962.

World Health Organization (WHO). Situation review and update on deafness, hearing loss and intervention programs proposed plans of action for prevention and alleviation of hearing impairment in countries of the SouthEast Asia Region. New Delhi: WHO Regional Office for South East Asia, 2007.

\section{How to cite this article:}

Anubhuti, P., R. Neela Rani, S.L. Kameswari and Sreedevi, P. 2018. A Study of Attributes of Hearing Impaired Children and Importance of Nutrition. Int.J.Curr.Microbiol.App.Sci. 7(07): 685-692. doi: https://doi.org/10.20546/ijcmas.2018.707.083 